\title{
Establishment of a Mouse Macula Densa Cell Line with an nNOS Promoter Driving EGFP Expression
}

\author{
Yukiko YasuOKA, Hideaki KaWAdA, Yoshiro SuZUKI, Masahiro SATO*, Hitoshi ENDOU, \\ Masuo OBINATA ${ }^{\dagger}$, and Katsumasa KAWAHARA
}

\begin{abstract}
Department of Physiology, Kitasato University School of Medicine, Sagamihara, 228-8555 Japan; *Division of Basic Molecular Science and Molecular Medicine, Tokai University School of Medicine, Isehara, 259-1193 Japan; and TDepartment of Cell Biology, Institute of Development, Aging and Cancer, Tohoku University, Sendai, 980-8575 Japan
\end{abstract}

\begin{abstract}
We describe a unique method for establishing a functionally intact macula densa cell line from immortalized renal cells in culture. The macula densa is involved in the tubuloglomerular feedback (TGF) system in the kidney and specifically expresses neuronal nitric oxide synthase (nNOS). A 347 bp portion of the nNOS promoter was used to drive the expression of enhanced green fluorescence protein (EGFP). An immortalized distal tubule (DT) cell line was derived from distal tubules microdissected from the kidneys of SV40 large T antigen transgenic
\end{abstract}

mice. Immunofluorescence labeling using an antibody against nNOS revealed no specific EGFP expression in immunofluorescence-negative DT cells. The established cell line (NE-MD) showed a time-dependent increase in signals of the nNOS protein when they were incubated with $12 \mu \mathrm{M}$ furosemide (an inhibitor of $\mathrm{Na}^{+}-$ $\mathrm{K}^{+}-2 \mathrm{Cl}^{-}$symporter) for $5 \mathrm{~h}$. In conclusion, this newly developed macula densa cell line will be useful in studies of the TGF system. [The Japanese Journal of Physiology 55: 365-372, 2005]

Key words: macula densa, neuronal nitric oxide synthase (nNOS), mouse kidney, furosemide, EGFP.

The macula densa (MD) is a plaque of specialized tubular cells within the end portion of the cortical thick ascending limb (cTAL), which is found in the angles between the afferent and efferent arterioles of the corresponding glomerulus [1]. MD cells monitor changes in the tubular $\mathrm{NaCl}$ concentration, whereby they regulate the glomerular filtration rate (GFR) by changing the sizes of the afferent and efferent arterioles. This negative feedback loop, known as the tubuloglomerular feedback (TGF) system, controls renal hemodynamics and extracellular fluid volume [2-5]. The microdissected juxtaglomerular apparatus (JGA), including MD cells, may be highly useful in vitro for studying the physiological and biochemical factors of the TGF system [6, 7]. However, freshly isolated MD cells, as well as the JGA, are not readily available because of their anatomical location in the kidney.
Therefore, the establishment of a highly differentiated MD cell line is of considerable importance because a supply of cultured MD cells would allow a powerful expansion of basic investigation. Yang et al. [8] have recently generated a mouse macula densa cell line, MMDD1, which was developed from transgenic mice for the SV40 large T-antigen (6-TgN(SV)7Bri) by using sorting methods with FITC and phycoerythrin fluorescence. However, MMDD1 cells resembling macula densa may not be genetically pure because they express NKCC1 [9], an isoform of NKCC2 (a $\mathrm{Na}^{+}-\mathrm{K}^{+}-2 \mathrm{Cl}^{-}$symporter [10]), localized in the inner medullary collecting duct (IMCD) [11].

nNOS is expressed in diverse cell types and tissues, such as skeletal muscle [12], pancreatic $\beta$ cells [13], and kidneys $[14,15]$. The finding that unique promoters participate in nNOS expression in unique cell types 
suggests that the expression of nNOS mRNA in tissues such as skeletal muscle and macula densa is subject to tissue-specific regulatory pathways [16]. This opens the possibility that MD cells can be visualized with the expression of enhanced green fluorescence protein (EGFP) and cloned from the primary culture of kidney distal tubule cells [15].

We first established immortalized renal tubular cell lines from transgenic mice harboring SV40 large T-antigen gene [17] by microdissecting distal tubules [18, 19]. We then developed a stable cell line expressing EGFP under the control of the nNOS promoter. The nNOS (NOS1) isoforms are expressed from a human genomic locus spanning $240 \mathrm{~kb}$ at $12 \mathrm{q} 24.2$ [20]. At least nine unique variants express in the noncoding exon 1 of nNOS mRNA [21]. Each exon 1 variant is tissue-specifically expressed [21], suggesting that the expression (of these variants) may be controlled by each tissue/cell-specific promoter located immediately upstream of each variant. In the present study, we used a promoter region of $347 \mathrm{bp}$ immediately upstream of the exon $1 \mathrm{c}$, which is reported to be preferentially active in the kidney [22]. Finally, we have successfully established a macula densa cell line with an nNOS-EGFP transgene (NE-MD). NE-MD cells exhibit unique properties of furosemide induction of nNOS protein expression.

\section{MATERIALS AND METHODS}

Materials. Collagenase (type I), G 418, bovine serumalbumin(BSA), $S$-nitroso- $N$-acetylpenicillamine (SNAP), and leupeptin were obtained from SigmaAldrich Inc. (St. Louis, MO, USA). Lipofectamine ${ }^{\mathrm{TM}}$, fetal bovine serum (FBS), penicillin-streptomycin, and trypsin/EDTA were from Invitrogen-Life Technologies (Carlsbad, CA, USA). Human transferrin was from Roche Diagnostics $\mathrm{GmbH}$ (Mannheim, Germany). RITC80-7 medium was from Kyokuto Pharmaceutical Industial (Tokyo). Insulin was from Nordisk Pharmacy (Tokyo). Recombinant human epidermal growth factor (rhEGF) was from Wakunaga Seiyaku (Tokyo). Dulbecco's modified Eagle's medium (DMEM) was from Nissui Seiyaku (Tokyo). Pentobarbital sodium salt was from Dainihon-seiyaku (Osaka). All other chemicals were of analytical grade from Waco Pure Chemical (Osaka). Polyvinylidene difluoride (PVDF) membrane and ECL kits were from Amersham Biosciences UK Limited (Little Chalfont Buckinghamshire, UK). Primary antibodies: antinNOS antibodies (Cayman Chemical Co., Ann Arbor, MI, USA) and mouse anti-actin monoclonal antibody
(Chemicon International Inc, Temecula, CA, USA). Secondary antibodies: A horseradish peroxidaseconjugated goat antirabbit or goat antimouse antibody (Amersham Biosciences).

Transgenic mouse strain. The origins and characteristics of SV40 large T-antigen expressing transgenic mice, provided by Dai-ichi Seiyaku (Tokyo), have been described elsewhere [17]. In brief, the immortalized cell lines were rapidly established from the primary culture of different tissues of this strain $[17,19]$. The established cell lines grew at a permissive temperature $\left(33^{\circ} \mathrm{C}\right)$, but not at a nonpermissive temperature $\left(39^{\circ} \mathrm{C}\right)$. The experimental protocol abided by the guidelines (1998) of the Kitasato Medical Experimental Animal Care Committee.

Distal tubule isolation and culture techniques. Distal tubules (DT) containing MD cells were microdissected from slices of kidney cortex according to the method described in previous papers $[18,19]$. Briefly, each mouse was anesthetized with pentobarbital sodium salt $(37.5 \mathrm{mg} / \mathrm{kg}$ body wt, I.P.) and was perfused through the heart with a dissociation solution, Dulbecco's modified Eagle's medium (DMEM), containing $1 \mathrm{mg} / \mathrm{ml}$ of collagenase type I. The cortex slices (approximately $1 \mathrm{~mm}$ thick) were incubated in the same dissociation solution for $30 \mathrm{~min}$ at $33^{\circ} \mathrm{C}$. The slices were rinsed twice and the distal tubules microdissected in Hanks' balanced salt solution (HBSS), containing $0.1 \% \mathrm{BSA}$, at $4^{\circ} \mathrm{C}$. The distal tubule (including the end portion of the cortical thick ascending limb of Henle's loop) was identified by its attachment to an original glomerulus [19]. The dissected distal tubules were maintained in RITC80-7 medium at $33^{\circ} \mathrm{C}\left(5 \% \mathrm{CO}_{2} / 95 \%\right.$ air). Media were supplemented with $5 \% \mathrm{FBS}, 10 \mu \mathrm{g} / \mathrm{ml}$ transferrin, 0.08 $\mathrm{U} / \mathrm{ml}$ insulin, $10 \mathrm{ng} / \mathrm{ml} \mathrm{rhEGF}, 50 \mathrm{U} / \mathrm{ml}$ penicillin, and $50 \mu \mathrm{g} / \mathrm{ml}$ streptomycin. When the DT cells became confluent after 7-10 days, they were maintained by subculture. The cells were used for experiments from passages 10 to 20 .

PCR. DNA fragments containing 5' and 3 ' deletions of the promoter region (347 bp) immediately upstream of exon 1c of human nNOS gene (GenBank Accession No.AJ308545) [22] were generated by PCR. Details of the $347 \mathrm{bp}$ are available upon request. Human genomic DNA (Cat. No. 6550-1; BD Biosciences [Clontech], Palo Alto, CA) was amplified by using a $279 \mathrm{~S}$ forward primer and a 49AS reverse primer. They correspond to nucleotides 5'-CAG ACG CTG CCA CTG CTG-3' and 5'-GTC ACC CCC TCT CAG ACA GTG$3^{\prime}$ of human nNOS gene, respectively. PCR was per- 
Table 1. Primers used for RT-PCR.

\begin{tabular}{|c|c|c|c|c|}
\hline Gene product & sequence (5'-3') & PCR product (bp) & $\begin{array}{l}\text { Annealing } \\
\text { temp. }\left({ }^{\circ} \mathrm{C}\right)\end{array}$ & References \\
\hline G-6-Pase & $\begin{array}{l}\text { GAA CGC CTT CTA TGT CCT CT } \\
\text { CAC CGG AAT CCA TAC GTT GA }\end{array}$ & 300 & 60 & 8 \\
\hline THP & $\begin{array}{l}\text { CTG GAT GTC CAT`AGT GAC TC } \\
\text { TGT GGC ATA GCA GTT GGT CA }\end{array}$ & 400 & 57 & 8 \\
\hline ROMK & $\begin{array}{l}\text { AGA AGA GGT GCT TTG GGG TT } \\
\text { GAT GCT TCT GAA CAC AGC CA }\end{array}$ & 313 & 60 & 26 \\
\hline NCC & $\begin{array}{l}\text { AAT GGC AAG GTC AAG TCG } \\
\text { TGA TGC GGA TGT CAT TGA TGG }\end{array}$ & 205 & 62 & 27 \\
\hline nNOS & $\begin{array}{l}\text { ATA CCA GCC TGA TCC ATG GA } \\
\text { CTC CAG GAG GGT GTC CAC }\end{array}$ & 591 & 58 & 28 \\
\hline COX-2 & $\begin{array}{l}\text { ACT CAC TCA GTT TGT TGA GTC ATT } \\
\text { TTT GAT TAG TAC TGT AGG GTT ATT }\end{array}$ & 583 & 58 & 29 \\
\hline NKCC1 & $\begin{array}{l}\text { CAG AGA CAA TTT GAA GAC C } \\
\text { CCA ACG TCA GCA TGA GAT }\end{array}$ & 681 & 58 & 9 \\
\hline NKCC2 & $\begin{array}{l}\text { CCC GCT CTC TTG GAT ATA TAA C } \\
\text { GCT CCG AAC AAA TTC TTC CG }\end{array}$ & 509 & 60 & 9 \\
\hline
\end{tabular}

formed in a reaction mixture $(100 \mu \mathrm{l})$ that contained $1 \times$ PCR buffer, $2.5 \mathrm{mM}$ dNTPs, 100 pmol of primers, $2.5 \mu 1$ of the human genomic DNA as a template, and 2.5 U of ExTaq DNA polymerase (Takara-Bio, Ohtsu) [23]. PCR conditions were $95^{\circ} \mathrm{C}, 5 \mathrm{~min}$ (incubation) and 30 cycles $95^{\circ} \mathrm{C}, 1 \mathrm{~min}$ (denaturation); $60^{\circ} \mathrm{C}, 1 \mathrm{~min}$ (annealing); and $72^{\circ} \mathrm{C}, 2$ min (extension) and finally $72^{\circ} \mathrm{C}, 7 \mathrm{~min}$. Unless otherwise indicated, all reactions were carried out at room temperature $\left(26-28^{\circ} \mathrm{C}\right)$.

DNA sequencing. The PCR product was isolated by the Wizard PCR Preps DNA purification system (Promega Co., Madison, WI, USA) and cloned into a pGEM-T Easy vector (Promega Co.), pGEM-T-N. The insert of pGEM-T-N was subjected to DNA sequence analysis by using an ABI Prism 3700 capillary sequencer (Applied Biosystems, Foster City, CA, USA).

Construction of the nNOS promoter-driven expression vector. The nNOS promoter sequence (347 bp) was excised from the vector by the digestion of pGEM-T-N with EcoRI and blunted and subcloned into the SalI-BamHI sites of pCE-29 [24, 25], yielding nNOS promoter-EGFP (pNE). An expression vector pNE-EGFP-1 was constructed by cloning the fragment from $\mathrm{pNE}$ in the SalI-SacI sites $(1.7 \mathrm{~kb})$ into the same sites of the promoterless EGFP vector, pEGFP-1 (Cat. No. 6086-1; BD Biosciences [Clontech]), to introduce the neomycin cassette.

Cloning of cells carrying the pNE-EGFP1 vector. The DT cells were transfected by using linearized pNE-EGFP-1 $(2 \mu \mathrm{g})$ with SalI and $4 \mu \mathrm{l}$ of Lipofectamine $^{\mathrm{TM}}$ Reagent (Invitrogen) per $35 \mathrm{~mm}$ dish.
The cells were incubated in G418-free RITC80-7 with $5 \% \mathrm{FBS}$ at $33^{\circ} \mathrm{C}$ for $24 \mathrm{~h}$ and maintained in RITC80-7 containing $0.8 \mathrm{mg} / \mathrm{ml}$ of G418. Media were changed every three days. Ten days after transfection, the clonal cells (G418-resistant cells expressing EGFP) were visualized under fluorescent microscopy (wavelength $530 \mathrm{~nm}$ ) and marked on the bottom of a culture dish. The fluorescent cells/colonies were mechanically peeled off and collected with a sterile yellow tip (EppendorfNetheler-Hinz GmbH, Hamburg, Germany). Collected cells expressing EGFP were gently trypsinized, washed, and sparsely plated in new $35 \mathrm{~mm}$ plastic dishes containing RITC80-7 medium with G418. Three or four days after seeding, the fluorescent colonies were again collected and plated. Finally, all the cells in a dish expressed stable EGFP. These fluorescent cell lines were named "NE-MD," since the clonal cells derived from DT cells carried the NE transgene in their own chromosomes.

RT-PCR. Total RNA was prepared from cultured NE-MD cells by using the Rneasy Mini kit (Qiagen, Hilden, Germany) according to the manufacturer's instructions. The positive control RNA used was Mouse Kidney Total RNA (BD Biosciences). One microgram of total RNA was used for reverse transcription with an RNA PCR kit (AMV), ver. 3.0 (Takara-Bio). The products were separated on Tris-acetate/EDTA 2\% agarose gels containing $100 \mathrm{ng} / \mathrm{ml}$ ethidium bromide. Sequences of all primers used in this study and the expected sizes of the amplification products are summarized in Table 1 [8, 9, 26-29]. ROMK (renal outer medullary 

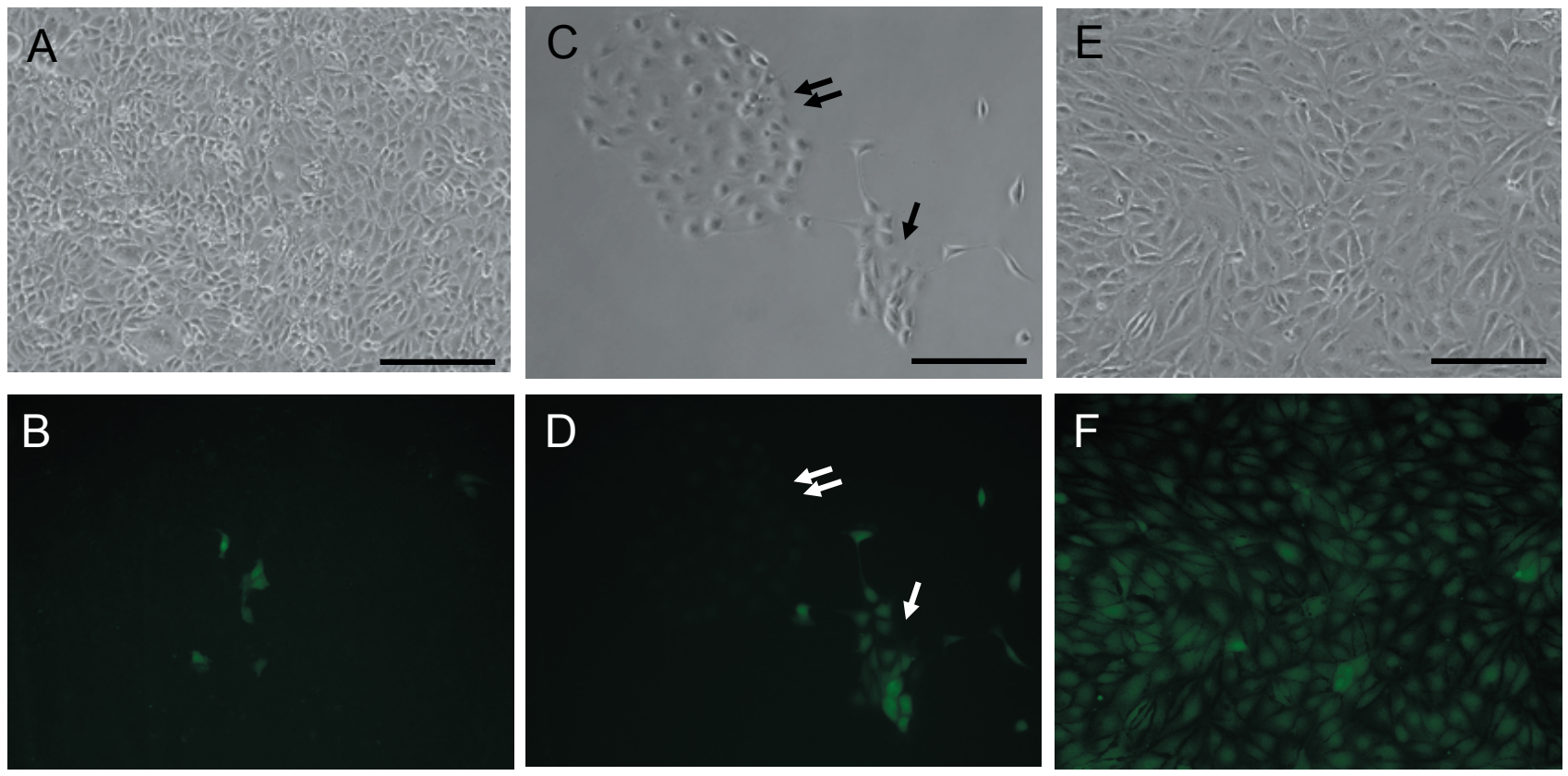

Fig. 1. Photomicrographs of phase-contrast (A, C, E) and fluorescence microscopy (B, D, F). DT cells transfected with pNE-EGFP-1 (2 days) (A, B). EGFP-positive and EGFPnegative colonies are, respectively, indicated by the single

potassium channel) mRNAs were widely expressed in the distal nephron, such as thick ascending limb and distal convoluted tubule [30]. Further, the immunoblot signals $(80 \mathrm{kDa})$ of anti-ROMK were equally stained between DT and NE-MD cells (unpublished data). Thus ROMK mRNA was used as an internal standard [31].

Immunoblot analysis. Immunoblot analysis was performed according to standard techniques [32, 33]. Transfected and nontransfected cells were incubated in lysis buffer (TBS containing [mM] 24 Tris, $136 \mathrm{NaCl}$, $2.6 \mathrm{KCl}$, and leupeptin, $\mathrm{pH}$ 7.4). The homogenates were centrifuged at $800 \mathrm{rpm}$ for $5 \mathrm{~min}\left(4^{\circ} \mathrm{C}\right)$ to remove cell debris. Supernatants were diluted in (SDS) sample buffer with $6 \% \beta$-mercaptoethanol. The proteins were denatured in boiling water for $10 \mathrm{~min}$, separated by polyacrylamide gel electrophoresis, and transferred to a (PVDF membrane). The blots were blocked for 30 min with $5 \%$ nonfat dry milk in Tris-buffered saline with $0.05 \%$ Tween 20 (TBS/T), followed by incubation overnight at $4^{\circ} \mathrm{C}$ with anti-nNOS antibodies (diluted $1: 10,000)$ and mouse antiactin monoclonal antibody (diluted 1:500). After washing with TBS/T, the blots were incubated with a horseradish peroxidase-conjugated goat antirabbit or goat antimouse secondary antibody for $2 \mathrm{~h}$. They were then washed with TBS/T and subjected to visualization with the use of ECL kits according to the manufacturer's instructions. and double arrows (7 days) (C, D). The establishment of nNOS-EGFP positive cells (10 days) (E, F). Note that all cells are EGFP-positive. The culture media contained G418 for selection. Bars indicate $200 \mu \mathrm{m}$.

\section{RESULTS}

\section{Transfection with linearized pNE-EGFP-1}

DT cells were transfected with a linearized pNEEGFP-1 vector encapsulated by Lipofectamine (Invitrogen), then cultured in the presence of G418 for at least 10 days. Two days after transfection, some clones exhibited bright EGFP, but others did not (Fig. 1, A and B). EGFP-expressing clones (Fig. 1, C and D) were mechanically peeled off and collected with a yellow tip under sterile conditions (see METHODS). This procedure was repeated several times until all cells of the clone expressed EGFP powerfully (Fig. $1, \mathrm{E}$ and $\mathrm{F})$. We finally established four clones, which were named the "NE-MD" cell line, nNOS-EGFP expressing macula densa. Confluent NE-MD cells have an epithelial, cobblestone morphology appearance on phase contrast light microscopy (Fig. 1E). EGFP-expressing cells look spindly under the same conditions (Fig. 1, C and D). One cell line of the NE-MD clones that strongly expresses EGFP has been characterized for the present study.

\section{Characterization of NE-MD cells}

The cell line used in the present study expresses mRNAs of specific markers for macula densa, including nNOS, NKCC2, and COX-2 (Fig. 2). It also expresses the renal outer medullary potassium channel 


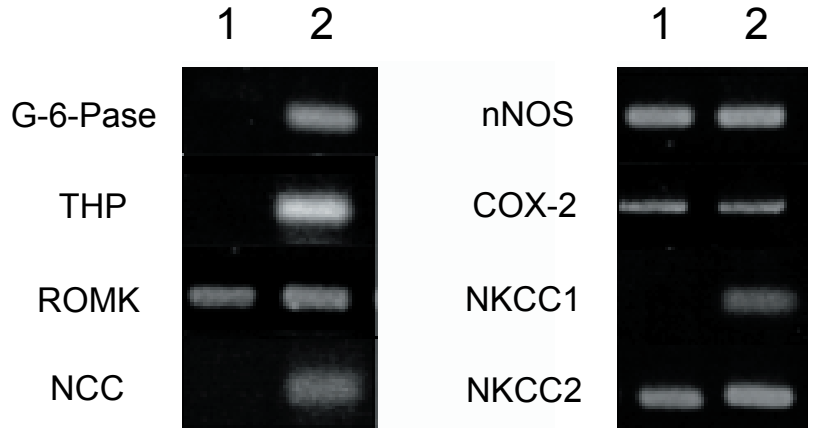

Fig. 2. RT-PCR analysis of total RNA from NE-MD cells and kidney. Characterization of NE-MD cells by RT-PCR of G-6-Pase, THP, ROMK, NCC, nNOS, COX-2, NKCC1, and NKCC2. Lane 1: NE-MD cells; lane 2: kidney cells. Kidney RNA was used as a positive control. ROMK was used as an internal standard.

(ROMK) mRNA, but does not express the mRNA for NKCC1 (Fig. 2). Moreover, glucose-6-phosphatase (G-6-Pase), Tamm-Horsfall protein (THP), and the thiazide-sensitive $\mathrm{Na}^{+}-\mathrm{Cl}^{-}$cotransporter (NCC), respectively, used as a marker for the proximal tubules, for the thick ascending limb of Henle (TAL), and for the distal convoluted tubule (DCT), were negative in the NE-MD cell line (Fig. 2).

\section{Induction of nNOS by furosemide}

The NE-MD and DT cells both were incubated with $12 \mu \mathrm{M}$ furosemide, an inhibitor of the $\mathrm{Na}^{+}-\mathrm{K}^{+}-$ $2 \mathrm{Cl}^{-}$transporter (NKCC2), for $0.5,1,2$, and $5 \mathrm{~h}$. Cell lysates of both cell lines were isolated at each time point and subjected to immunoblot analysis by the use of anti-nNOS antibodies. Signals of the nNOS proteins in NE-MD cells increased significantly in a timedependent manner, but no increase was observed in the DT cells (Fig. 3).

\section{DISCUSSION}

By utilizing the nNOS promoter-driven expression of EGFP, we established a unique macula densa cell line (NE-MD) from cultured kidney distal tubule (DT) cells obtained from SV40 large T-antigen transgenic mice. In the present study, a vector carrying the nNOS promoter and EGFP cDNA was successfully introduced into the genome of DT cells. The macula densa cell line "NE-MD" was established, using a promoter region (347 bp) immediately upstream of the exon 1c of nNOS [22], and therefore it is unique and completely different from MMDD1, mouse kidney macula densa cells [8].

The molecular mechanisms underlying tissue (cell type)-specific expression and the diverse sizes of nNOS proteins appear to be the utilization of alternative promoters [16]. Major bands in brain and skeletal muscle, respectively, have been found at approximately $155 \mathrm{kDa}$ and $164 \mathrm{kDa}$ [34]. In MMDD1 [8] and NE-MD cells, the proteins were stained strongly at approximately 100 and faintly at about $65 \mathrm{kDa}$. Since the nNOS gene is single, it is probable that isoforms of the nNOS proteins are generated by each of the different tissue/cell-specific promoters [22]. In the kidney, at least three kinds of nNOS mRNA (carrying sequences corresponding to the exons $1 \mathrm{c}, 1 \mathrm{f}$, and $1 \mathrm{~g}$ of the $\mathrm{nNOS}$ gene at their 5 ' end) are expressed [22]. Therefore the expression of these mRNA may be regulated by each of the promoters upstream of the noncoding 1st exons. It is not unusual that nNOS molecules would differ in molecular size in the kidney and skeletal muscle. In the present study, we used a $347 \mathrm{bp}$ promoter region immediately upstream of exon $1 \mathrm{c}$ of the nNOS gene to express EGFP in DT cells, and nNOS in a skeletal muscle has an additional 34 amino acid insert, encoded by $102 \mathrm{bp}$ sequences, between the calmodulin-binding site and the flavin mononucleotide (FMN)-binding site of nNOS [34].

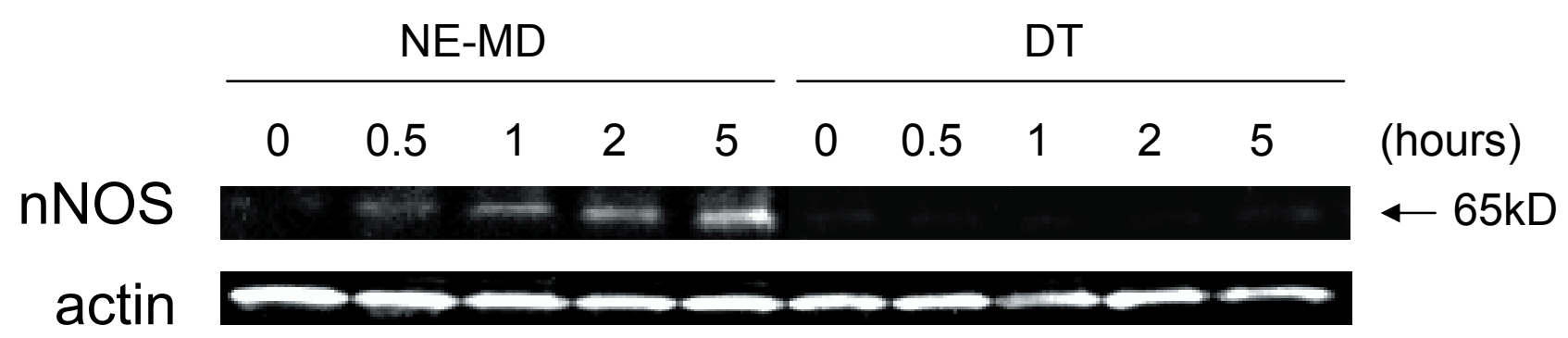

Fig. 3. Representative immunoblots of protein extracts of NE-MD and DT cell lines after furosemide treatment. Quiescent kidney cells were stimulated with $12 \mu \mathrm{M}$ furosemide. Proteins were extracted from NE-MD or DT cells at $0,0.5,1,2$ and $5 \mathrm{~h}$ after treatment with furosemide and subjected to immunoblotting, using antibodies against $\mathrm{nNOS}$ and actin. 


\section{Y. YASUOKA et al.}

NE-MD cells, which originate from cultured DT cells, express mRNAs of specific markers for the macula densa, including nNOS [28], NKCC2 [8], and COX-2 [29]. Furthermore, they do not express markers for other nephron segments, such as G-6-Pase for the proximal tubules [9], THP for TAL with the exception of the macula densa [8], and NCC for DCT [27]. Thus we believe that a cell line of NE-MD is a valid model of the kidney macula densa. There is no difference between NE-MD and MMDD1 [8,9] in terms of the expression patterns of G-6-Pase, THP, nNOS, COX-2, ROMK $[35,36]$, and NKCC2. However, the staining of NKCC1 mRNA was different between the two cell lines. NKCC1 mRNA was not detectable in NE-MD in the present study, whereas it is strongly positive in MMDD1 cells [9]. This result is consistent with the reported properties of the macula densa of the mouse kidney, in which the NKCC1 (BSC2) protein is not detectable. The NKCC1 protein is localized in the terminal IMCD [11].

This is the first reported observation that nNOS expression in cultured macula densa cells (NE-MD) is enhanced by an application of furosemide. Immunoblot analysis in the present study revealed a staining of the $\mathrm{nNOS}$ protein $(65 \mathrm{kDa})$ to be faint, but significant, in NE-MD cells, though practically no detectable signal was observed in DT cells. More important, signals of nNOS increased time-dependently when NE-MD cells were incubated with $12 \mu \mathrm{M}$ furosemide, an inhibitor of the $\mathrm{Na}^{+}-\mathrm{K}^{+}-2 \mathrm{Cl}^{-}$symporter. These findings may be consistent with the regulation of nNOS in vivo by salt restriction $[28,37,38]$ as well as an application of angiotensin II [39] or furosemide [40]; however, the cellular mechanism remains unclear. The furosemideinduced nNOS expression in rat kidney [40] and cultured NE-MD cells in the present study is apparently different from previous observations that furosemide activates renin synthesis on afferent arterioles freshly isolated from the rat kidney [41], and that a generation of $\mathrm{NO}$ occurs only at elevated levels of $[\mathrm{NaCl}]_{1}[42]$. Further, nNOS activity in the macula densa is reported to be stimulated by the increased intracellular $\mathrm{pH}$ [43] caused by alterations of luminal $\mathrm{NaCl}$ concentration [44]. However, these functional studies interrelate macula densa luminal $\mathrm{NaCl}$ uptake with nNOS activity and do not rule out the possibility that the expression of nNOS protein or mRNA is increased by furosemide. Thus it is perhaps not surprising that the expression of nNOS is regulated at various levels, including the genomic pathway [39], though the expression of nNOS (NOS I, bNOS) is constitutive [8, 14, 15, 37, 45, 46].
In conclusion, the NE-MD cell line established in the present study should also prove helpful in assessing these issues.

This study was supported by a grant from Research Projects (2002-03) of the Kitasato University Graduate School of Medical Sciences to K. K. Special thanks to Y. Nakabayashi for her technical assistance. Parts of this study were presented at the 35th IUPS/EB 2005 in San Diego, CA, USA, April 2005.

\section{REFERENCES}

1. Kriz W and Kaissling B: Structural organization of the mammalian kidney. In: The Kidney: Physiolojy and Pathophysiology, ed. Seldin DW and Giebisch G, Raven Press, New York, 1985

2. Thurau $\mathrm{K}$ and Schnermann J: The sodium concentration in the macula densa cells as a regulating factor for glomerular filtration. Klin Wochenschr 43: 410-413, 1965

3. Persson AEG, Schnermann J, and Wright FS: Modification of feedback influence on glomerular filtration rate by acute isotonic extracellular volume expansion. Pflügers Arch 381: 99-105, 1979

4. Inscho EW, Mitchell KD, and Navar LG: Extracellular ATP in the regulation of renal microvascular function. FASEB J 8: 319-328, 1994

5. Komlosi P, Fintha A, and Bell PD: Current mechanisms of macula densa cell signalling. Acta Physiol Scand 181:463-469, 2004

6. Bell PD, Lapointe JY, Sabirov R, Hayashi S, Peti-Peterdi J, Manabe K, Kovacs G, and Okada Y: Macula densa cell signaling involves ATP release through a maxi anion channel. Proc Natl Acad Sci USA 100: 4322-4327, 2003

7. Ito $S$ and Ren Y: Evidence for the role of nitric oxide in macula densa control of glomerular hemodynamics. J Clin Invest 92: 1093-1098, 1993

8. Yang T, Park JM, Arend L, Huang Y, Topaloglu R, Pasumarthy $A$, Praetorius $H$, Spring K, Briggs JP, and Schnermann J: Low chloride stimulation of prostaglandin $\mathrm{E}_{2}$ release and cyclooxygenase-2 expression in a mouse macula densa cell line. J Biol Chem 275: 37922-37929, 2000

9. He H, Podymow T, Zimpelmann J, and Burns KD: NO inhibits $\mathrm{Na}^{+}-\mathrm{K}^{+}-2 \mathrm{Cl}^{-}$cotransport via a cytochrome P-450dependent pathway in renal epithelial cells (MMDD1). Am J Physiol 284: F1235-F1244, 2003

10. Kaplan MR, Plotkin MD, Lee W-S, Xu Z-C, Lytton J, and Hebert SC: Apical localization of the Na-K-Cl cotransporter, rBSC1, on rat thick ascending limbs. Kidney Int 49: 40-47, 1996

11. Kaplan MR, Plotkin MD, Brown D, Hebert SC, and Delpire E: Expression of the mouse Na-K-2Cl cotransporter, mBSC2, in the terminal inner medullary collecting duct, the glomerular and extraglomerular mesangium, and the glomerular afferent arteriole. J Clin Invest 98: 723-730, 1996 
12. Nakane M, Schmidt HH, Pollock JS, Förstermann U, and Murad F: Cloned human brain nitric oxide synthase is highly expressed in skeletal muscle. FEBS Lett 316: 175-180, 1993

13. Schmidt $H H$, Warner TD, Ishii K, Sheng $H$, and Murad F: Insulin secretion from pancreatic B cells caused by L-arginine-derived nitrogen oxides. Science 255: $721-$ 723, 1992

14. Wilcox CS, Welch WJ, Murad F, Gross SS, Taylor G, Levi R, and Schmidt HHHW: Nitric oxide synthase in macula densa regulates glomerular capillary pressure. Proc Natl Acad Sci USA 89: 11993-11997, 1992

15. Kone BC and Baylis C: Biosynthesis and homeostatic roles of nitric oxide in the normal kidney. Am J Physiol 272: F561-F578, 1997

16. Wang $Y$ and Marsden PA: Nitric oxide synthases: gene structure and regulation. In: Nitric Oxide: Biochemistry, Molecular Biology, and Therapeutic Implications, ed. Ignarro L and Murad F, Academic Press, San Diego, 1995

17. Yanai N, Satoh T, Kyo S, Abe K, Suzuki M, and Obinata $\mathrm{M}$ : A tubule cell line established from transgenic mice harboring temperature-sensitive Simian Virus 40 large T-antigen gene. Jpn J Cancer Res 82: 1344-1348, 1991

18. Nonoguchi H, Uchida S, Shiigai T, and Endou H: Effect of chronic metabolic acidosis on ammonia production from L-glutamine in microdissected rat nephron segments. Pflügers Arch 403: 229-235, 1985

19. Hosoyamada M, Obinata M, Suzuki M, and Endou $H$ : Cisplatin-induced toxicity in immortalized renal cell lines established from transgenic mice harboring temperature sensitive SV40 large T-antigen gene. Arch Toxicol 70: 284-292, 1996

20. Hall AV, Antoniou H, Wang $Y$, Cheung AH, Arbus AM, Olson SL, Lu WC, Kau CL, and Marsden PA: Structural organization of the human neuronal nitric oxide synthase gene (NOS1). J Biol Chem 269: 33082-33090, 1994

21. Wang $Y$, Newton DC, Robb GB, Kau CL, Miller TL, Cheung $\mathrm{AH}$, Hall AV, VanDamme S, Wilcox JN, and Marsden PA: RNA diversity has profound effects on the translation of neuronal nitric oxide synthase. Proc Natl Acad Sci USA 96: 12150-12155, 1999

22. Saur D, Seidler B, Paehge H, Schusdziarra V, and Allescher HD: Complex regulation of human neuronal nitric-oxide synthase exon 1c gene transcription. Essential role of Sp and ZNF family members of transcription factors. J Biol Chem 277: 25798-25814, 2002

23. Sato M, Kasai K, and Tada N: A sensitive method of testing for transgenic mice using polymerase chain reaction-Southern hybridization. Genetic Anal Biomol Eng 12: 109-111, 1995

24. Niwa H, Yamamura K, and Miyazaki J: Efficient selection for high-expression transfectants with a novel eukaryotic vector. Gene 108: 193-199, 1991

25. Sato M, Ishikawa $A$, and Kimura M. Direct injection of foreign DNA into mouse testis as a possible in vivo gene transfer system via epididymal spermatozoa. Mol Reprod Devel 61: 49-56, 2002
26.Bachmann S, Mutig K, Bates J, Welker P, Geist B, Gross V, Luft FC, Alenina N, Bader M, Thiele BJ, Prasadan K, Raffi HS, and Kumar S: Renal effects of Tamm-Horsfall protein (uromodulin) deficiency in mice. Am J Physiol 288: F559-F567, 2005

27. Gonzalez-Nunez D, Morales-Ruiz M, Leivas A, Hebert $\mathrm{SC}$, and Poch E: In vitro characterization of aldosterone and CAMP effects in mouse distal convoluted tubule cells. Am J Physiol 286: F936-F944, 2004

28. Singh I, Grams M, Wang WH, Yang T, Killen P, Smart A, Schnermann J, and Briggs JP: Coordinate regulation of renal expression of nitric oxide synthase, renin, and angiotensinogen mRNA by dietary salt. Am J Physiol 270: F1027-F1037, 1996

29. Hung JH, Su IJ, Lei HY, Wang HC, Lin WC, Chang WT, Huang W, Chang WC, Chang YS, Chen CC, and Lai $\mathrm{MD}$ : Endoplasmic reticulum stress stimulates the expression of cyclooxygenase-2 through activation of NFkappaB and pp38 mitogen-activated protein kinase. J Biol Chem 279: 46384-46392, 2004

30. Boim MA, Ho K, Shuck ME, Bienkowski MJ, Block JH, Slightom JL, Yang Y, Brenner BM, and Hebert SC: ROMK inwardly rectifying ATP-sensitive $\mathrm{K}^{+}$channel. II. Cloning and distribution of alternative forms. Am J Physiol 268: F1132-F1140, 1995

31. Suzuki Y, Yasuoka Y, Shimohama T, Nishikitani M, Nakamura N, Hirose S, and Kawahara K: Expression of the $\mathrm{K}^{+}$channel Kir7.1 in the developing rat kidney: role in $\mathrm{K}^{+}$excretion. Kidney Int 63: 969-975, 2003

32. Tao Y, Kim J, Stanley M, He Z, Faubel S, and Schrier RW: Pathways of caspase-mediated apoptosis in autosomal-dominant polycystic kidney disease (ADPKD). Kidney Int 67: 909-919, 2005

33. Ni J, Cnops Y, Debaix H, Boisde I, and Verbavatz J-M: Functional and molecular characterization of a peritoneal dialysis model in the C57BL/6J mouse. Kidney Int 67: 2021-2031, 2005

34. Silvagno $\mathrm{F}, \mathrm{Xia} \mathrm{H}$, and Bredt DS: Neuronal nitric-oxide synthase- $\mu$, an alternatively spliced isoform expressed in differentiated skeletal muscle. J Biol Chem 271: 11204-11208, 1996

35. Kawahara K and Anzai N: Potassium transport and potassium channels in the kidney tubules. Jpn J Physiol. 47: 1-10, 1997

36. Noulin JF, Brochiero E, Coady MJ, Laprade R, and Lapointe JY: Molecular identity and regulation of renal potassium channels. Jpn J Physiol. 51: 631-47, 2001

37. Tojo A, Kimoto M, and Wilcox CS: Renal expression of constitutive NOS and DDAH: separate effects of salt intake and angiotensin. Kidney Int 58: 2075-2083, 2000

38. Hocherl K, Kammerl M, Kees F, Kramer BK, Grobecker $\mathrm{HF}$, and Kurtz A: Role of renal nerves in stimulation of renin, COX-2, and nNOS in rat renal cortex during salt deficiency. Am J Physiol 282: F478-F484, 2002

39. Wilcox CS: Role of macula densa NOS in tubuloglomerular feedback. Curr Opin Nephrol Hypertens 7: 443449, 1998

40. Bosse HM, Bohm R, Resch S, and Bachmann S: Parallel regulation of constitutive NO synthase and renin at JGA of rat kidney under various stimuli. Am J Physiol 269: F793-F805, 1995 


\section{Y. YASUOKA et al.}

41. Tharaux PL, Dussaule JC, Pauti MD, Vassitch Y, Ardaillou R, and Chatziantoniou C: Activation of renin synthesis is dependent on intact nitric oxide production. Kidney Int 51: 1780-1787, 1997

42. Lie R, Pittner J, and Persson AEG: Changes of cell volume and nitric oxide concentration in macula densa cells caused by changes in luminal $\mathrm{NaCl}$ concentration. J Am Soc Nephrol 13: 2688-2696, 2002

43. Liu R, Carretero OA, Ren Y, and Garvin JL: Increased intracellular $\mathrm{pH}$ at the macula densa activates nNOS during tubuloglomerular feedback. Kidney Int 67: 1837-1843, 2005
44. Liu R and Persson AEG: Simultaneous changes of cell volume and cytosolic calcium concentration in macula densa cells caused by alterations of luminal $\mathrm{NaCl}$ concentration. J Physiol (Lond) 563: 895-901, 2005

45. Terada Y, Tomita K, Nonoguchi H, and Marumo F: Polymerase chain reaction localization of constitutive nitric oxide synthase and soluble guanylate cyclase messenger RNAs in microdissected rat nephron segments. J Clin Invest 90: 659-665, 1992

46. Bachmann S, Bosse HM, and Mundel P: Topography of nitric oxide synthesis by localizing constitutive NO synthases in mammalian kidney. Am J Physiol 268: F885-F898, 1995 